Louisiana State University

LSU Digital Commons

$5-1-2015$

\title{
Plant neighborhood effects on herbivory: Damage is both density and frequency dependent
}

Tania N. Kim

Florida State University

Nora Underwood

Florida State University

J. T. Cronin

Follow this and additional works at: https://digitalcommons.Isu.edu/biosci_pubs

\section{Recommended Citation}

Kim, T., Underwood, N., \& Cronin, J. (2015). Plant neighborhood effects on herbivory: Damage is both density and frequency dependent. Ecology, 96 (5), 1431-1437. https://doi.org/10.1890/14-1097.1 


\title{
Plant neighborhood effects on herbivory: damage is both density and frequency dependent
}

\author{
TAnia N. Kim ${ }^{1}$ and Nora Underwood
}

Department of Biological Science, Florida State University, Tallahassee, Florida 32306-4295 USA

\begin{abstract}
Neighboring plants can affect the likelihood that a focal plant is attacked by herbivores. Both the density of conspecific neighbors (resource concentration or dilution effects) and the relative density of heterospecific neighbors (associational effects or effects of neighbor frequency) within the local neighborhood can affect herbivore load and plant damage. Understanding how these neighborhood effects influence processes such as plant competition or natural selection on plant resistance traits will require knowing how both plant density and frequency affect damage, but previous studies have generally confounded density and frequency effects. In this study, we independently manipulated the absolute density and frequency (i.e., relative density) of two plant species (Solanum carolinense and Solidago altissima) to characterize neighborhood composition effects on $S$. carolinense damage by herbivores, providing the first picture of how both density and frequency of neighbors influence damage in a single system. We found both a positive effect of $S$. carolinense density on $S$. carolinense damage (a resource concentration effect) and a nonlinear effect of $S$. altissima frequency on $S$. carolinense damage (associational susceptibility). If these types of patterns are common in nature, future studies seeking to understand neighborhood effects on damage need to incorporate both density and frequency effects and capture any nonlinear effects by selecting a range of values rather than focusing on only a pair of densities or frequencies. This type of data on neighborhood effects will allow us to understand the contribution of neighborhood effects to population-level processes such as competition, the evolution of plant resistance to herbivores, and yield gains in agricultural crop mixtures.
\end{abstract}

Key words: associational effects; associational resistance; associational susceptibility; dilution effects; old-field; resource concentration effects; Solanum carolinense; Solidago altissima.

\section{INTRODUCTION}

Simple and commonly used models of plant population dynamics and natural selection on plant resistance assume all individuals experience identical local neighborhoods (e.g., Harper 1977). In nature, however, plants are heterogeneously distributed and the conditions of the biotic neighborhood around an individual plant can affect its growth, reproduction, and survival (Waller 1981, Silander and Pacala 1985). One way local neighborhoods can influence plant performance is by changing the likelihood of herbivore attack. For example, the density of conspecific neighbors can increase or decrease the likelihood of damage through changes in herbivore load and feeding behavior; these

Manuscript received 7 June 2014; revised 15 September 2014; accepted 22 September 2014. Corresponding Editor: J. T. Cronin.

${ }^{1}$ Present address: Great Lakes Bioenergy Research Center, University of Wisconsin, Madison, Wisconsin 537264084 USA. E-mail: tkim@glbrc.wisc.edu are referred to as resource concentration effects (Root 1973) or dilution effects (Otway et al. 2005), respective1y. Likewise, the relative density (or frequency) of neighboring heterospecific plants can reduce the likelihood or amount of damage (associational resistance; Tahvanainen and Root 1972) or increase it (associational susceptibility; Letourneau 1995). The same kinds of effects could occur within plant species when the local density and frequency of different plant genotypes influence herbivore attack. Although a large literature tests for the existence of these neighborhood effects (Andow 1991, Agrawal et al. 2006; reviewed in Barbosa et al. 2009), examines potential mechanisms (e.g., predator attraction, host-plant apparency), and discusses the application of associational effects to agroecosystems (e.g., diversified planting, trap-cropping), the long-term consequences of neighborhood effects for population and community level processes in plantherbivore interactions are still poorly understood (Barbosa et al. 2009, Underwood et al. 2014). This is in part because we lack the empirical data necessary to 
parameterize models that could determine how neighborhood effects influence these longer-term processes.

To determine how neighborhood effects on damage influence population and community level processes, we need to know how damage changes with both the density and frequency of neighboring plants. Models of population-level processes such as plant competition suggest that both density and frequency influence outcomes and thus need to be accounted for. For example, theory on apparent competition suggests that density and frequency dependent herbivore attack should contribute to the coexistence of competitors (Holt and Kotler 1987). The first step toward understanding the long-term consequences of neighborhood effects is thus to determine whether damage is indeed influenced differently by plant density and frequency. If so, we should include both these effects in models to see whether neighborhood effects on damage influence processes such as plant competition or natural selection on plant resistance. Theory suggests that conspecific plant density and heterospecific frequency should influence damage differently because herbivores rely on different cues at different spatial scales to detect and select host plants (Hambäck et al. 2014). Host choice involves several hierarchical processes that include detecting patches of host plants within a matrix of non-host plants (between-patch processes) and choosing host plants within a patch (within-patch processes) and different herbivore species may vary in their responses to host plant cues (Hambäck and Englund 2005). Thus neighbor effects on damage should vary depending on herbivore and plant traits, and with spatial scale (SaintGermain et al. 2004, Bergvall et al. 2006, Hambäck et al. 2014), but no study has yet characterized the form of both conspecific density and neighbor frequency effects on damage in the same system.

To provide a full picture of how plant neighborhood influences damage, experimental studies need to manipulate independently both density and frequency components of the neighborhood. While previous experimental studies tell us that the presence or absence of neighbors is important, in most cases these studies confound different neighborhood components (e.g., plant density and frequency in substitutive designs [Letourneau 1995, Orians and Bjorkman 2009]; total density and frequency in additive designs [Rand 1999, Hambäck et al. 2000]). Observational studies that measure neighbor densities or distance to neighbors and correlate these features with damage patterns (e.g., Sholes 2008) have the same problem. In theory, experiments with the same plant and insect species could even show either associational susceptibility or associational resistance, depending on whether a substitutive or additive design is used (Hambäck et al. 2014); this can occur when both density and frequency dependent effects are present and one or both are nonlinear. These confounding issues can be over- come with a response surface experimental design (Inouye 2001) that independently varies the density and frequency of plants across a broad range. This design provides a full picture of neighborhood effects on damage, including both conspecific density effects (resource concentration or dilution effects) and heterospecific frequency effects (associational effects).

While theory suggests that both conspecific plant density and heterospecific frequency can influence herbivore damage and that these effects can be nonlinear (Hambäck et al. 2014), to our knowledge no previous study has empirically described both resource concentration and associational effects. In this study, we used a response surface experimental design to examine how the density of a focal plant species (Solanum carolinense) and the frequency of a neighboring plant species (Solidago altissima) affect insect herbivore damage to the focal plant species. This full characterization of neighborhood effects on herbivore damage allowed us to determine whether resource concentration, dilution, and associational effects are occurring simultaneously, whether they differ in magnitude, and whether their forms are linear or nonlinear. Answers to these questions will help us understand how neighborhood effects on damage can be integrated into our understanding of population level processes such as plant competition and the evolution of traits conferring resistance to herbivores.

\section{Methods \\ Study system}

This study took place in an old field in north Florida in 2007 (Mission Road Research Facility, Florida State University, Tallahassee, Florida, USA). Our focal plant species was Solanum carolinense (Carolina horsenettle) and its neighboring plant species was Solidago altissima (Tall goldenrod). Solanum carolinense (Solanaceae) and S. altissima (Asteraceae) are perennial herbaceous plants native to the eastern United States (Werner et al. 1980, Bassett and Munro 1986). Both species reproduce sexually and asexually, and co-occur in disturbed areas such as early successional fallow agricultural fields and roadsides. Both plant species support a diversity of insect herbivores including leaf chewers, phloem feeders, gall makers, and leaf miners. In Florida, the primary herbivores on $S$. carolinense are specialist leaf-chewing insects such as the false potato beetle, Leptinotarsa juncta (see Plate 1); tobacco hornworm, Manduca sexta; and eggplant flea beetle, Epitrix fuscula. For S. altissima, some of the common herbivores in Florida include sap suckers (e.g., red goldenrod aphids, Uroleucon sp.; spittle bugs, Clastoptera sp.) and specialized internal feeders (e.g., gall making midges, Eurosta solidaginis and Rhopalomyia solidaginis). In addition to specialist herbivores, both $S$. carolinense and S. altissima are fed upon by generalist insects including beet army worm 
(Spodoptera exigua), cabbage looper (Trichoplusia ni), and grasshoppers (Melanoplus, Aptenopedes, and Schistocerca species). In north Florida, $S$. carolinense generally receives a greater amount of damage compared to S. altissima (Kim et al. 2013).

\section{Experimental design}

We examined how "neighborhood composition" (i.e., $S$. carolinense density and the frequency of S. altissima) influenced $S$. carolinense leaf damage using a response surface experimental design. In April-May, plants were clonally propagated from greenhouse-grown root cuttings $(1.3-1.7 \mathrm{~g})$, kept in the greenhouse for six weeks $\left(12-17 \mathrm{~cm}\right.$ in height), and then transplanted into $1-\mathrm{m}^{2}$ field quadrats in June. Preliminary analyses were conducted at three spatial scales, taking into account the density and frequency of neighbors within neighborhoods around $S$. carolinense of varying sizes $(25 \mathrm{~cm}$ radius circles around an individual $S$. carolinense, $1 \mathrm{~m}$ radius circles, and $4 \mathrm{~m}$ radius circles). Results suggest that neighborhoods at $1 \mathrm{~m}$ best explained variation in damage (Appendix A). We established four total densities of plants $\left(1,6,12,18\right.$ individuals per $1-\mathrm{m}^{2}$ quadrat) with varying combinations of $S$. carolinense and $S$. altissima (13 density combinations or neighborhood types in total, Fig. 1). Densities of S. carolinense and $S$. altissima spanned the range of naturally occurring densities in surrounding areas, and each neighborhood type was replicated three times (39 1-- ${ }^{2}$ quadrats in total). Quadrats were separated by $1.5 \mathrm{~m}$ of weed mat and arranged into three spatial blocks separated by $12-30 \mathrm{~m}$. A detailed description of the plant propagation protocol and experimental design can be found in Kim et al. (2013).

At the end of the growing season and before leaf senescence (September), leaf damage (measured as percent leaf area removed) was assessed on all $S$. carolinense leaves and averaged per individual. The presence and absence of damage by leaf miners and aphids were also recorded. The effects of total plant density, $S$. carolinense density, and frequency of $S$. altissima (proportion of $S$. altissima in the quadrat) on $S$. carolinense damage were analyzed using a generalized linear model in R 2.12 ( $\mathrm{R}$ Development Core Team 2010). Significant effects of $S$. carolinense density would indicate resource concentration or dilution effects, while effects of $S$. altissima frequency would indicate associational resistance or susceptibility. The unit of analysis was each density combination (i.e., quadrat), therefore $S$. carolinense damage was averaged across all $S$. carolinense individuals within each quadrat. We suspected a nonlinear relationship between $S$. carolinense damage and the frequency of $S$. altissima so both linear and quadratic terms were included as predictor variables. Because the spatial location of the quadrats could influence damage, spatial block was also included as a

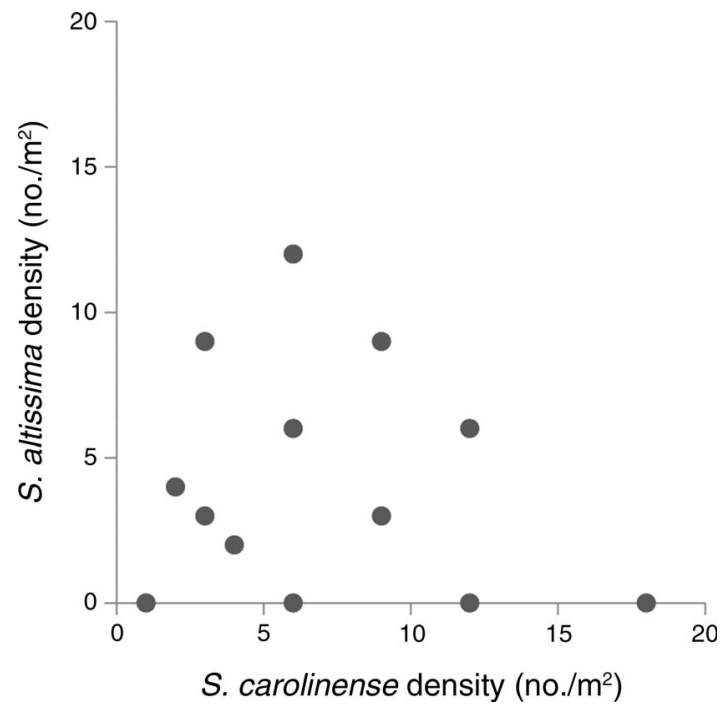

FIG. 1. Thirteen density combinations of Solanum carolinense and Solidago altissima (response surface experimental design). Each point represents the composition of $S$. carolinense and S. altissima within each $1-\mathrm{m}^{2}$ quadrat (i.e., neighborhood). Each neighborhood type was replicated three times. Note that at any fixed density of plants within each $1-\mathrm{m}^{2}$ quadrat (except neighborhoods with only one $S$. carolinense individual), the frequency (or relative density) of $S$. carolinense and S. altissima changes as you fan diagonally across the surface.

fixed main effect in the model (due to having only three blocks) along with block interactions with $S$. carolinense density and $S$. altissima frequency. We performed stepwise model selection using the Akaike information criterion (AIC); models with lower AIC values ( $\triangle \mathrm{AIC}>$ 2) are considered better fit models (Burnham and Anderson 2002). Total density and all interactions were dropped during the stepwise process $(\triangle \mathrm{AIC}$ from full model $=22.19)$. Spatial block was later dropped from the model because models with block effects were similar in fit to models without block effects $(\triangle \mathrm{AIC}$ from final model with block $=1.75)$; dropping block did not change relationships or patterns of significance for other variables. We visualized neighborhood effects on damage first by constructing the full response surface that includes both density and frequency effects, and second, by plotting density and frequency effects separately (as in most previous studies).

\section{RESUlts}

Leaf damage to $S$. carolinense was extensive (mean leaf tissue damage $=27 \%$; range, $3.3-62.2 \%$ ) and was largely due to external leaf-chewing insects, with minimal damage by aphids and leaf miners $(<1 \%$ of $S$. carolinense individuals). On the other hand, damage to S. altissima was low (mean leaf tissue damage $=10.2 \%$; range 2.6-22.4\%). In the presence of neighbors (regardless of the total density and identity of neighbors), $S$. 


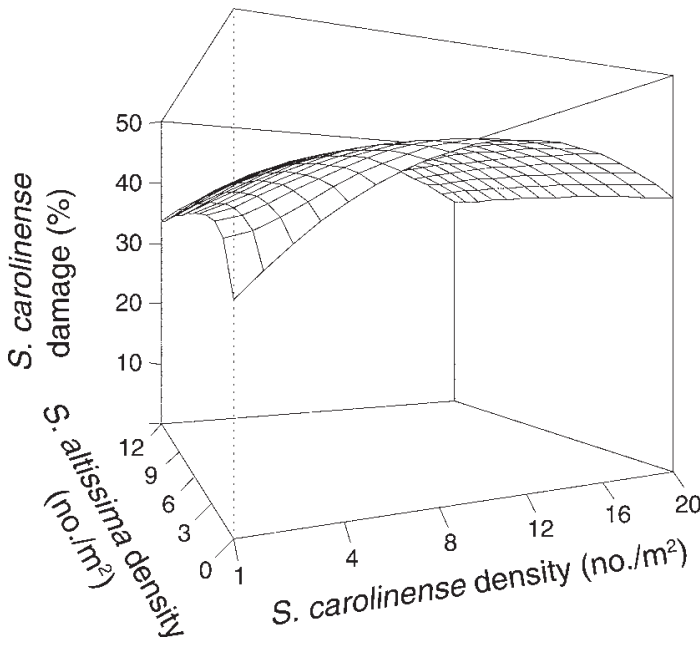

FIG. 2. Fitted surface for neighborhood effects on insect damage to Solanum carolinense. There are significant effects of $S$. carolinense density (resource concentration effects) and $S$. altissima density (associational susceptibility) to $S$. carolinense damage. Plant densities are in number of individuals $/ \mathrm{m}^{2}$. Damage is percentage of leaf area removed by herbivores.

carolinense individuals suffered higher damage (mean $=$ $28.5 \%)$ than $S$. carolinense individuals growing alone (mean $=15.35 \%, t=-4.08, \mathrm{df}=10, P=0.001)$. Neighboring plants thus increased $S$. carolinense damage, but the magnitude and form of this susceptibility depended on neighborhood composition (Fig. 2). There was a positive linear relationship between the density of $S$. carolinense and damage $\left(F_{1,35}=6.649, P=0.014\right.$, $\Delta$ AIC from full model $=22.19$, Fig. 3a), indicating a resource concentration effect. At the same time, there was also a nonlinear (unimodal) relationship between the frequency of $S$. altissima and $S$. carolinense damage (significant quadratic effect of Solidago frequency, $F_{2,35}$ $=5.496, P=0.008, \Delta$ AIC from full model with no quadratic terms $=5.24$, Fig. 3b), indicating associational susceptibility. As the frequency of $S$. altissima increased, $S$. carolinense damage increased, reaching peak damage levels when neighborhoods were approximately $40 \%$ occupied by S. altissima and then declining with further increases in $S$. altissima frequency. There was no interaction between density and frequency. We conducted the same analysis with $S$. altissima as the focal plant and there were significant conspecific density, heterospecific frequency, and total density effects (Appendix B). However, given the low damage to S. altissima overall, and the low percent of the variance explained by these neighborhood factors (highest $R^{2}$ was approximately 0.08 , Appendix C), these effects are unlikely to be biologically very significant.

\section{DisCUSSION}

In this study, conspecific density and heterospecific frequency both influenced damage to plants, producing both resource concentration effects and associational susceptibility. Both density and frequency effects increased damage to $S$. carolinense, but the forms of these functions differed; density effects were linear whereas frequency effects were nonlinear. If this type of pattern is common in nature, studies seeking to understand neighborhood effects on damage need to incorporate both density and frequency effects. The fact that we found nonlinear neighbor effects suggests that future studies need to measure density and frequency effects across a range of values rather than focusing on only a pair of densities or frequencies.

The density of $S$. carolinense and S. altissima frequency had different relationships with damage
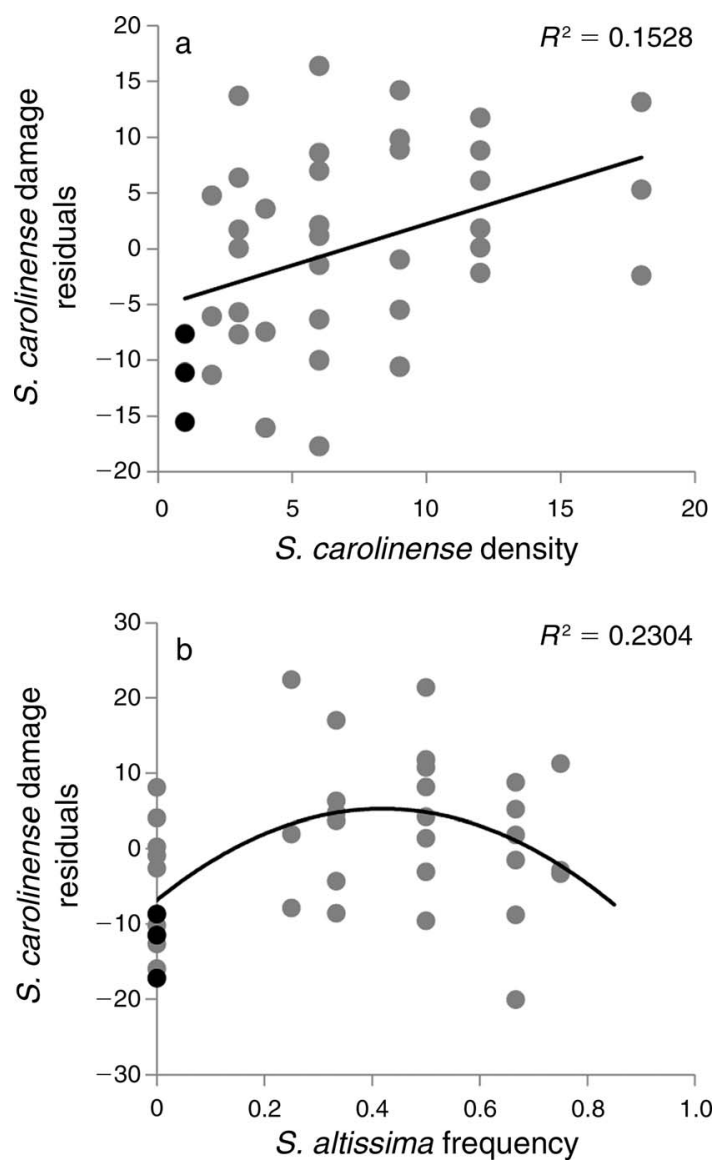

FIG. 3. Neighborhood composition effects on Solanum carolinense leaf tissue damage (mean percentage of leaf area removed). Black, filled circles indicate treatments with only one $S$. carolinense individual per $1-\mathrm{m}^{2}$ quadrat. (a) $S$. carolinense density effects on $S$. carolinense damage residuals (after accounting for S. altissima frequency effects), (b) S. altissima frequency effects on $S$. carolinense damage residuals (after accounting for $S$. carolinense density effects). Densities are in number of individuals $/ \mathrm{m}^{2}$. Plant frequencies are the proportion of individuals $/ \mathrm{m}^{2} . R^{2}$ values were calculated with the residuals after accounting for the effects of $S$. altissima frequency on damage (a) and effects of $S$. carolinense density on damage (b). 
suggesting that multiple mechanisms could be operating to influence plant damage, although data from this experiment do not allow distinguishing among mechanisms. The positive relationship between $S$. carolinense density and damage may have been due to increased herbivore attraction to high density neighborhoods due to stronger cues emitted by host plants (i.e., a resource concentration effect; Root 1973) and/or due to a numerical response of herbivores to resources (i.e., a bottom up effect; Strong et al. 1984). Both mechanisms could have been operating in this study. Several generations of the dominant herbivores of $S$. carolinense could have occurred over the course of our four-month study (L. juncta and M. sexta are both multivoltine in northern Florida) and separate experiments in this system indicate that L. juncta foraging does respond to plant density (Kim 2012). Variation in plant quality may contribute to the hump-shaped relationship between damage and $S$. altissima frequency. The observed increase in damage from low to moderate S. altissima frequency could result from $S$. altissima outcompeting $S$. carolinense for resources, thus reducing $S$. carolinense investment in anti-herbivore defenses. Other experiments in this system support effects of $S$. altissima competition on $S$. carolinense leaf palatability to herbivores (Kim 2012). However, at very high $S$. altissima frequency, damage could have decreased because of an increase in powdery mildew prevalence. Powdery mildew was more prevalent on $S$. carolinense in neighborhoods that had higher frequencies of $S$. altissima, and L. juncta seems to avoid S. carolinense leaves with powdery mildew (T. Kim, personal observation). If effects of the frequency of $S$. altissima on $S$. carolinense damage are in fact mediated by powdery mildew, this would be an indirect associational effect. Further studies are needed to test all possible mechanisms for plant density and frequency effects on damage in this system and to determine how they might interact.

The form and strength of neighbor effects are likely to vary with the spatial scale of the neighborhood being considered. We measured neighborhood effects at the 1$\mathrm{m}^{2}$ scale. While preliminary analyses suggested that neighborhood effects at this scale were stronger than slightly smaller and larger scales (Appendix A), a continuous characterization of neighborhood effects over a range of scales might find other scales with different effects. Damage by herbivores involves processes that include locating host plant patches and hostplant selection within a patch (Hambäck et al. 2014) and herbivores rely on different cues at different spatial scales to detect and select host plants. Ideally one would measure neighborhood effects at a range of different scales and changes in effects across scales might suggest which mechanisms are most relevant at each scale. Although it is known that the influence of plant neighbors can decrease with distance between plants
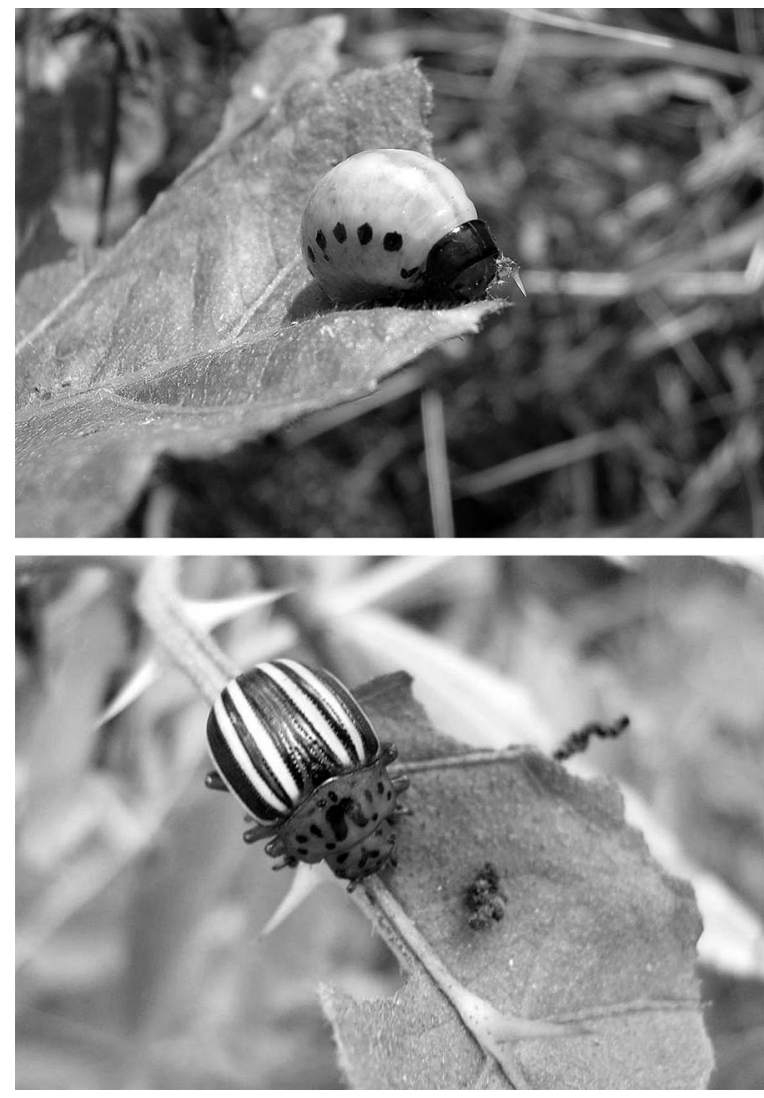

Plate 1. (Upper) Leptinotarsa juncta late-instar larva and (lower) L. juncta adult feeding on Solanum carolinense leaves. Photo credits: Steve Halpern, Pacific University.

(Dangremond et al. 2010), and that neighborhood influences herbivore movement among patches (Bergvall et al. 2006, Hambäck et al. 2009), data on how neighborhood effects on damage vary with spatial (and temporal) scales are lacking and needed.

Neighborhood effects on damage might have longterm implications for plant populations and communities, and it has been suggested that damage and neighborhood composition should feedback to influence each other (Stastny and Agrawal 2014). In our system, such feedbacks are possible; damage was density and frequency dependent (results from present study) and we know that damage can influence plant biomass and competition (Kim et al. 2013) and demography (Underwood and Halpern 2012), thus influencing plant density and frequencies. The next step in linking neighborhood effects to population dynamics would be to use findings from the current paper, plus data on competition in the absence of herbivores, to parameterize models to determine whether or how neighborhood effects through herbivores might contribute to population dynamics in combination with other processes such as competition 
(Underwood et al. 2014). The fact that we found nonlinear relationships between damage and neighborhood composition suggests that these dynamics could be complex. For $S$. carolinense, decreased damage at low densities (Fig. 3a) might contribute to the rapid increase in $S$. carolinense invading disturbed areas, since herbivores are known to reduce the rate of $S$. carolinense increase (Underwood and Halpern 2012). In the absence of further disturbance, $S$. altissima outcompetes $S$. carolinense forming nearly monospecific stands in old fields (Hartnett and Bazzaz 1985, Kim et al. 2013). As $S$. altissima becomes more frequent, the exclusion of $S$. carolinense could be accelerated because of increasing damage to $S$. carolinense (increasing portion of nonlinear relationship between $S$. altissima frequency and $S$. carolinense damage, Fig. 3b). However, decreased damage to $S$. carolinense at high frequencies of $S$. altissima, (decreasing portion of curve, Fig. 3b) could slow the exclusion of $S$. carolinense from the system. Although competition by $S$. altissima is likely to have stronger effects on $S$. carolinense than reductions in herbivory at high $S$. altissima frequencies, in our area, $S$. carolinense can persist at low numbers under dense $S$. altissima stands. This may be in part due to reduced damage, which might alleviate the negative effects of competition by S. altissima (Kim et al. 2013).

Previous studies have demonstrated that neighborhood context influences damage (reviewed by Barbosa et al. 2009), but they have not been able to assess how different components of the neighborhood influence damage. Our study demonstrates that damage can be both density and frequency dependent; this is the first step to understanding the long-term implications of neighborhood effects for plant populations and communities. Understanding neighbor effects on damage is relevant to determining how plant density and frequency influence competition between plant species, and the evolution of plant resistance, since neighborhoods of plant genotypes with different resistance traits should influence selection by herbivores (Tuomi et al. 1994, Agrawal et al. 2006, Rautio et al. 2012). Similarly, the density and frequency of plants in an area can influence visitation and pollination rates, and thus are relevant to competition for pollinators and the evolution of plant floral traits (Levin and Anderson 1970, Thomson 1978, Mitchell et al. 2009). Understanding neighborhood effects also has obvious applications to conservation and agriculture. If management goals are to reduce insect damage to target plants (e.g., crops, reintroduced native plants) or increase pollinator abundances (e.g., hedgerows, pollinator stripes), knowing how both plant density and frequency components of the neighborhood influence damage and pollination would help in designing the most effective approaches to planting and habitat management.

\section{ACKNOWLEDGMENTS}

We thank B. D. Inouye, B. J. Spiesman, T. E. Miller, A. A. Winn, and two anonymous reviewers for helpful comments on earlier drafts of the manuscript. We also thank the staff at the Mission Road Research Facilities at Florida State University for logistical support. This research was supported by the Robert K. Godfrey award in Botany to T. N. Kim and NSF DEB-0717221 to N. Underwood.

\section{Literature Cited}

Agrawal, A. A., J. A. Lau, and P. Hambäck. 2006. Community heterogeneity and the evolution of interactions between plants and insect herbivores. Quarterly Review of Biology 81:349-376.

Andow, D. A. 1991. Vegetational diversity and arthropod population response. Annual Review of Entomology 36:561586.

Barbosa, P., J. Hines, I. Kaplan, H. Martinson, A. Szczepaniec, and Z. Szendrei. 2009. Associational resistance and associational susceptibility: having right or wrong neighbors. Annual Review of Ecology and Systematics 40:1-20.

Bassett, I. J., and D. B. Munro. 1986. The biology of Canadian weeds. 78. Solanum carolinenese L. and Solanum rostratium Dunal. Canadian Journal of Plant Science 66:977-991.

Bergvall, U. A., P. Rautio, K. Kesti, J. Tuomi, and O. Leimar. 2006. Associational effects of plant defences in relation to within- and between-patch food choice by a mammalian herbivore: neighbour contrast susceptibility and defence. Oecologia 147:253-260.

Burnham, K. P., and D. R. Anderson. 2002. Model selection and multi-model inference: a practical information-theoretic approach. Springer-Verlag, New York, New York, USA.

Dangremond, E. M., E. A. Pardini, and T. M. Knight. 2010. Apparent competition with an invasive plant hastens the extinction of an endangered lupine. Ecology 91:2261-2271.

Hambäck, P. A., J. Agren, and L. Ericson. 2000. Associational resistance: insect damage to purple loosestrife reduced in thickets of sweet gale. Ecology 81:1784-1794.

Hambäck, P. A., M. Björkman, B. Ramert, and R. J. Hopkins. 2009. Scale-dependent responses in cabbage herbivores affect attack rates in spatially heterogeneous systems. Basic and Applied Ecology 10:228-236.

Hambäck, P. A., and G. Englund. 2005. Patch area, population density and the scaling of migration rates: the resource concentration hypothesis revisited. Ecology Letters 8:10571065.

Hambäck, P. A., B. D. Inouye, P. Andersson, and N. Underwood. 2014. Searching for food in complex environments: a theory for relative attraction and associational effects. Ecology 95:1370-1383.

Harper, J. L. 1977. Population biology of plants. Academic Press, London, UK.

Hartnett, D. C., and F. A. Bazzaz. 1985. The genet and ramet population-dynamics of $S$. altissima canadensis in an abandoned field. Journal of Ecology 73:407-413.

Holt, R. D., and B. P. Kotler. 1987. Short-term apparent competition. American Naturalist 130:412-430.

Inouye, B. D. 2001. Response surface experimental designs for investigating interspecific competition. Ecology 82:26962706.

Kim, T. N. 2012. Community-level consequences of plantherbivore interactions. Dissertation. Florida State University, Tallahassee, Florida, USA.

Kim, T. N., N. Underwood, and B. D. Inouye. 2013. Insect herbivores change the outcome of plant competition through both inter- and intraspecific processes. Ecology 94:17531763. 
Letourneau, D. K. 1995. Associational susceptibility: effects of cropping pattern and fertilizer on Malawian bean fly levels. Ecological Applications 5:823-829.

Levin, S. A., and W. W. Anderson. 1970. Competition for pollinators between simultaneously flowering species. American Naturalist 104:455-467.

Mitchell, R. J., R. J. Flanagan, B. J. Brown, N. M. Waser, and J. D. Karron. 2009. New frontiers in competition for pollination. Annals of Botany 103:1403-1413.

Orians, C. M., and C. Bjorkman. 2009. Associational resistance to a tropical leaf-miner: does neighbour identity matter? Journal of Tropical Ecology 25:551-554.

Otway, S. J., A. Hector, and J. H. Lawton. 2005. Resource dilution effects on specialist insect herbivores in a grassland biodiversity experiment. Journal of Animal Ecology 74:234240.

R Development Core Team. 2010. R: a language and environment for statistical computing. R Foundation for Statistical Computing, Vienna, Austria. www.r-project.org

Rand, T. A. 1999. Effects of environmental context on the susceptibility of Atriplex patula to attack by herbivorous beetles. Oecologia 121:39-46.

Rautio, P., U. A. Bergvall, J. Tuomi, K. Kesti, and O. Leimar. 2012. Food selection by herbivores and neighbourhood effects in the evolution of plant defences. Annales Zoologici Fennici 49:45-57.

Root, R. B. 1973. Organization of a plant-arthropod association in simple and diverse habitats - fauna of collards (Brassica oleracea). Ecological Monographs 43:95-120.

Saint-Germain, M., P. Drapeau, and C. Hebert. 2004. Landscape-scale habitat selection patterns of Monochamus scutellatus (Coleoptera: Cerambycidae) in a recently burned black spruce forest. Environmental Entomology 33:17031710.
Sholes, O. D. V. 2008. Effects of associational resistance and host density on woodland insect herbivores. Journal of Animal Ecology 77:16-23.

Silander, J. A., and S. W. Pacala. 1985. Neighborhood predictors of plant performance. Oecologia 66:256-263.

Stastny, M., and A. Agrawal. 2014. Love thy neighbor? Reciprocal impacts between plant community structure and insect herbivory in co-occurring Asteraceae. Ecology 95: 2904-2914.

Strong, D. R., J. H. Lawton, and T. R. E. Southwood. 1984. Insects on plants: community patterns and mechanisms. Harvard University Press, Cambridge, Massachusetts, USA.

Tahvanainen, J. O., and R. B. Root. 1972. Influence of vegetational diversity on population ecology of a specialized herbivore, Phyllotreta cruciferae (Coleoptera-Chrysomelidae). Oecologia 10:321-346.

Thomson, J. D. 1978. Effects of stand composition on insect visitation in two-species mixtures of Hieracium. American Midland Naturalist 100:431-440.

Tuomi, J., M. Augner, and P. Nilsson. 1994. A dilemma of plant defences: is it really worth killing the herbivore? Journal of Theoretical Biology 170:427-430.

Underwood, N., and S. Halpern. 2012. Insect herbivores, density dependence, and the performance of the perennial herb Solanum carolinense. Ecology 93:1026-1035.

Underwood, N., B. D. Inouye, and P. A. Hambäck. 2014. A conceptual framework for associational effects: when do neighbors matter and how would we know? Quarterly Review of Biology 89:1-19.

Waller, D. M. 1981. Neighborhood competition in several violet populations. Oecologia 51:116-122.

Werner, P. A., I. K. Bradbury, and R. S. Gross. 1980. The biology of Canadian weeds. 45. Solidago canadensis L. Canadian Journal of Plant Science 60:1393-1409.

\section{Supplemental Material}

\section{Ecological Archives}

Appendices A-C are available online: http://dx.doi.org/10.1890/14-1097.1.sm 